\title{
LA-UR-20-20218
}

Approved for public release; distribution is unlimited.

Title: Drum Handling, Ergonomic Best Practices

Author(s): $\quad$ Stender, Kerith

Splittstoesser, Riley

Monroe, Kimberly

Intended for: Best-practices guide to share with other DOE labs

Issued: 
Disclaimer:

Los Alamos National Laboratory, an affirmative action/equal opportunity employer, is operated by Triad National Security, LLC for the National Nuclear Security Administration of U.S. Department of Energy under contract 89233218CNA000001. By approving this article, the publisher recognizes that the U.S. Government retains nonexclusive, royalty-free license to publish or reproduce the published form of this contribution, or to allow others to do so, for U.S. Government purposes. Los Alamos National Laboratory requests that the publisher identify this article as work performed under the auspices of the U.S. Department of Energy. Los Alamos National Laboratory strongly supports academic freedom and a researcher's right to publish; as an institution, however, the Laboratory does not endorse the viewpoint of a publication or guarantee its technical correctness. 
Memorandum

Industrial Hygiene and Safety
From: Kimberly Monroe, ADESHQ,

Contract Ergonomist

Kerith Stender, IHS-CS,

Ergo Program Leader

Phone: 667-4644

Symbol: IHS-CS: $11-020$

Date: October 19, 2011

\section{Subject: Drum Handling, Ergonomic Best Practices}

\section{Summary}

Kerith Stender and Kimberly Monroe conducted an ergonomic assessment of the drum handling tasks performed at several sites at LANL. Drum handling tasks at TA-50 Building 69 were reviewed on May 26 ${ }^{\text {th }}, 2011$ with Fred Moya. A meeting was held with Joe Abeyta, Jose Chavez, and Don Thorp on July 13th, 2011 to discuss drum handling issues and manual material handling equipment specifications. A second meeting was held on August 9th, 2011 with Stephanie Jacquez, Juan Garcia and Alfred Vallo to review issues associated with drum handling at TA-54. Alfred Vallo toured the domes at TA-54 with Kimberly Monroe on August 11th, 2011. At that time, employee feedback was solicited from multiple employees handling drums throughout the area. A final review meeting was held on September $28^{\text {th }}$ with Kimberly Monroe, Kerith Stender, and Juan Garcia to finalize this report.

This assessment focused primarily on the manual handling of 55 gallon drums. The physical effects of each task are dependent on the process, work area layout and equipment utilized. The following drum transportation processes were identified:

- TA54 to TA50, to be repacked

- TA50 to TA54, repacked

- TA50 to TA54, liquid waste

- TA55 to TA54, TRU drums

- TA54 to Rant, WIP certified

- CMR to TA54

The primary concern of employees with regards to this task is the force required to "break" the drum. Several risk exposures were identified with the current practice.

- Strains from manual manipulation of the large, heavy drums, including back, shoulder, arm, or leg strains. These types of injuries are often cumulative in nature and could be compounded by age or other activities or tasks performed.

- Stuck-by injuries from falling or tipping drums.

- Chemical exposure from the manual handling of materials. This exposure could be the result of a spill, splash, or residual material on the outside of the drum.

- Environmental risks if the drum contents spill. Each time that the drum is handled or transferred increases the risk of a spill.

Generally speaking, manual handling of drums should be eliminated where feasible. A number of vendors sell specialty equipment for handling of drums. Different approaches may be 
appropriate depending upon the area layout, constraints, the type and number of drums handled, etc.

NIOSH estimates approximately $17-20 \%$ of overexertion injuries are related to pushing and pulling tasks. However, this number does not include slips and falls that occur while performing a pushing or pulling task. The 2009 Bureau of Labor Statistics data includes several statistics that are relevant to the risk exposure associated with drum handling tasks. In 2009,

- three event or exposure categories accounted for 62 percent of total injuries and illnesses requiring days away from work for all ownership sectors: contact with objects and equipment; overexertion; and fall on same level.

- overexertion accounted for 22 percent of all occupational injuries and illnesses.

- sprain, strain, and tear injuries accounted for 40 percent of total injury and illness cases requiring days away from work in all ownerships.

- Soreness and pain (including the back) accounted for 11 percent of total cases.

- 42 percent of sprains, strains, and tears were the result of overexertion.

- Bodily reaction (such as bending, reaching, twisting or slipping without falling) accounted for another 22 percent.

- 11 percent were the results of falls on the same level.

- In 37 percent of the sprain, strain and tear cases, the back was injured.

- In another 27 percent of the cases, a lower extremity (typically the knee or ankle) was injured.

- $\quad$ sprain, strain, and tear cases where the shoulder was injured required a median of 22 days to recover, more than twice as many median days than for all sprain, strain, and tear cases.

When evaluating pushing and pulling tasks, the force values considered are not the same as the weight of the object(s) being pushed or pulled. They refer to the applied force required to push or pull an object to initiate movement in either a horizontal or vertical direction. Ergonomic guidelines on maximum recommended push and pull forces are included the end of this report in Appendix A.

Due to the wide number of locations where drum handling is performed and the variety of drum sizes handled, implementation of the recommendations in this memorandum will require a dedicated effort on the part of both management and employees. Employee involvement and buy-in is critical to the success of this initiative. It is important that their feedback be solicited throughout the entire process. 


\begin{tabular}{|c|c|}
\hline ISSUES & ACTIONS/RECOMMENDATIONS \\
\hline $\begin{array}{l}\text { 1. "Breaking" drums } \\
85 \text { gallon drums weigh } 153 \text { pounds and } \\
\text { are } 39.5 \text { " tall. The pallet height raises } \\
\text { the top of the drum an additional 6". } \\
\text { The } 55 \text { gallon drums vary in weight. } \\
\text { The general rule of thumb used is that } \\
\text { if the drum weighs more than } 350 \\
\text { pounds then two employees will move } \\
\text { the drum. }\end{array}$ & $\begin{array}{l}\text { a. Eliminate Need to Break Drums } \\
\text { It is recommended that the entire drum handling } \\
\text { process throughout LANL be evaluated step-by- } \\
\text { step. This analysis can then be used to identify } \\
\text { opportunities to eliminate re-handling of drums } \\
\text { and to utilize material handling equipment. Drum } \\
\text { handling equipment recommendations are } \\
\text { provided throughout this report. Additional } \\
\text { sources are included in Appendix B. }\end{array}$ \\
\hline $\begin{array}{l}\text { In addition to the push/pull forces, } \\
\text { pinch points are also a concern when } \\
\text { breaking the drums. Employees noted } \\
\text { that on a fully loaded pallet with four } \\
\text { drums, the first drum is the most } \\
\text { difficult to break. This is due to } \\
\text { clearance access and available locations } \\
\text { for hand holds. }\end{array}$ & $\begin{array}{l}\text { b. New Employee Training, Best Practices } \\
\text { For situations where drum handling equipment } \\
\text { cannot be utilized, it is recommended that each area } \\
\text { develop employee technique training on best } \\
\text { practices for body positioning when breaking } \\
\text { drums. Appendix C contains an example of } \\
\text { technique instructions specifically for employees } \\
\text { that manually tilt and roll } 55 \text { gallon drums. }\end{array}$ \\
\hline \multirow[t]{3}{*}{$\begin{array}{l}\text { At Building 54-282, a Valley Craft } \\
\text { corner drum dolly is available. } \\
\text { However, employees noted that the } \\
\text { hook doesn't always reach to the rim of } \\
\text { the drum where it is located on a pallet. } \\
\text { A Wesco drum grabber is available as } \\
\text { well, but it only works on one of the } \\
\text { fork lifts and can only be used to handle } \\
55 \text { gallon metal drums. }\end{array}$} & $\begin{array}{l}\text { c. Lever/Pry Bar } \\
\text { Consider using some type of lever or pry bar like is } \\
\text { used in the telecommunications industry for man- } \\
\text { hole covers or by the Rigors when handling } \\
\text { extremely heavy equipment such as breaking safes. } \\
\text { These tasks have similar concerns: forceful } \\
\text { exertions, heavy loads, possible uneven footing, } \\
\text { and awkward postures. }\end{array}$ \\
\hline & An example of a lever dolly is shown below. \\
\hline & $\begin{array}{l}\text { Lever Dolly } \\
\text { "Lever dolly with 6' long steel handle and kick bar. } \\
5000 \text { pound capacity" }\end{array}$ \\
\hline
\end{tabular}


2. Movement of drums.

The conditions vary depending on where the drums are being picked up from. In general, drums are loaded four to a pallet. Awkward postures and the forceful exertions increase when accessing the two drums on the back of the pallet., both when loading and unloading the pallet.

At some of the dome locations, a Wesco Drum Grab is used to individually lift single drums and place them onto the end of the trailer. At Pad 10, the drum grab was used with $6^{\prime}$ tines on the forklift to lift the drum and place it inside the trailer at the desired location.

\section{DJ55 DRUM GRAB}

by wescon

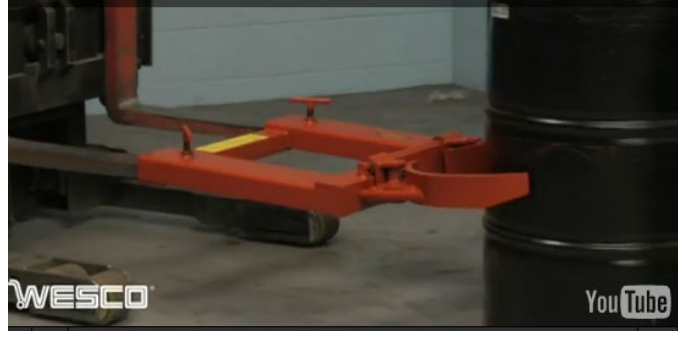

Wesco 55 Gallon Drum Grabs

Wesco also makes a drum grab that can be used for both 55 and 85 gallon drums. Employees expressed stability concerns with the use of this drum grab since the edges of the grabber only grip the front portion of the 85 gallon drum. Employees also indicated that there are only one or two drum grabs available for the eleven domes. They often manually move the drums instead of looking for the drum grab. If they do look for the grab, it is often in need of inspection and out of service.

For some of the drum transfers, pallet jacks are not used inside the trailer since the pallet jack available does not meet DOE Packaging and Transportation requirements. a. Leave Drums on Pallet

Can the drums be loaded into the trailer and remain on the pallet? This would significantly reduce the number of times each drum is manually handled during transport.

During the TA-54 tour, David George, the DOE Representative at LANL was at building 375 . He mentioned that for some of the transfers within TA54 , they were able to use non-combustible hydraulic fluid on the pallet jacks in order to enable them to be transported on the truck with the load.

The feasibility of this for use on loads on public roads was discussed with Ashok Kappor during a phone interview on August 22 ${ }^{\text {nd }}, 2011$.

Ashok Kapoor, Safety Engineer, STSM

Office of Packaging and Transportation,

EM-45, U.S. Department of Energy

Washington, DC 20585

ashok.kapoor@hq.doe.gov, 301-903-6756

For reference, Ashok provided Section 16 of the DOE Explosive Safety Manual pertaining to offsite/onsite transportation for safe handling of explosive shipments. Refer to Appendix D for an excerpt from the manual including the material handling equipment requirement. It is recommended that the DOE requirements be reviewed in more detail with the LANL Packaging and Transportation representative Robert Murphy, 505-665-6437, to identify design requirements for manual material handling equipment that can be used during transport of drums onsite to minimize re-handling.

b. Portable Dock

Consider a portable dock. One possible source is shown below.
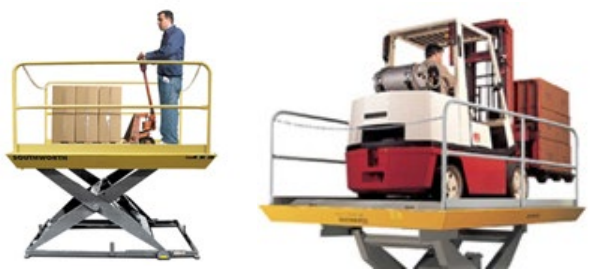

Southworth Loading Dock Lift

Case Study of DuraDock 


\begin{tabular}{|c|c|}
\hline & 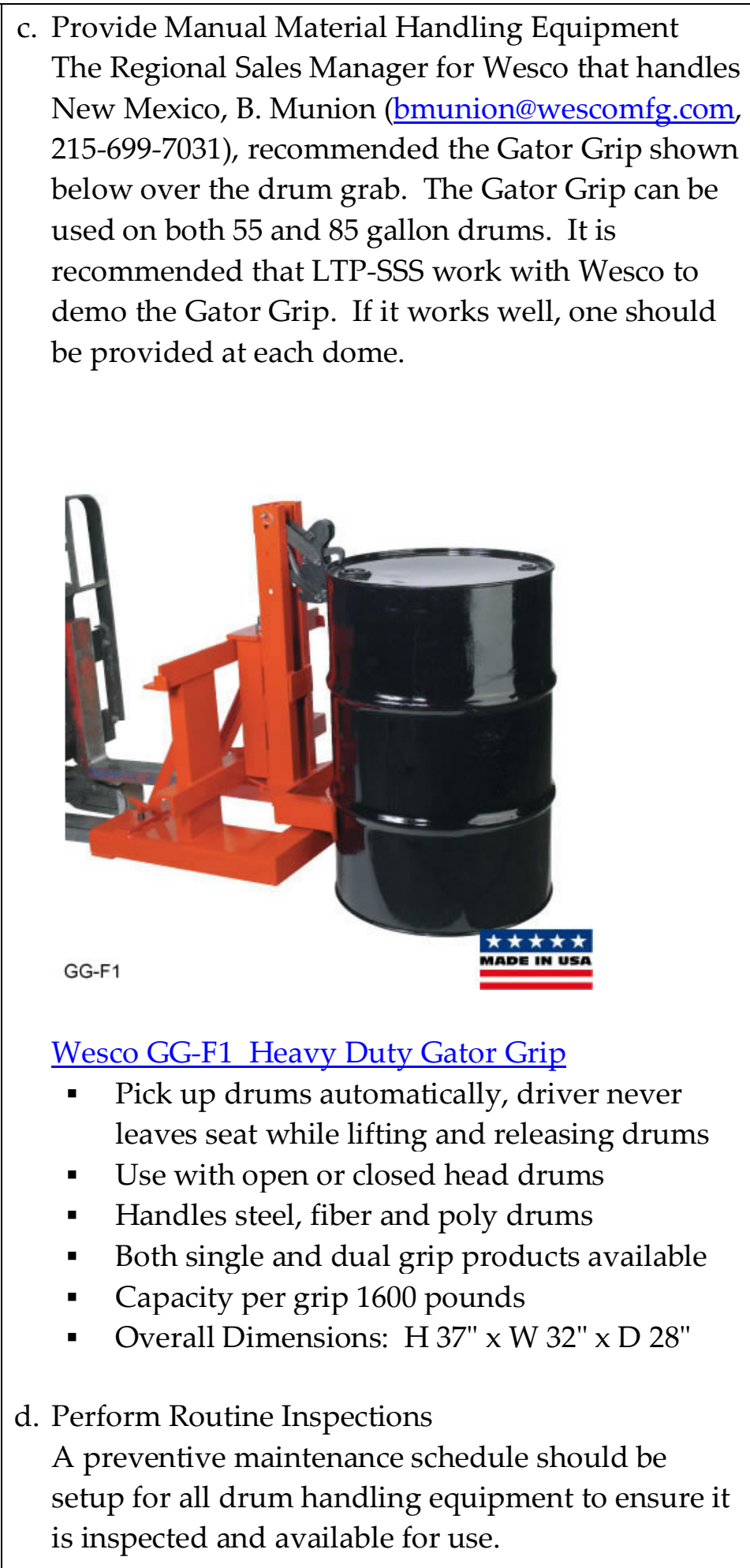 \\
\hline $\begin{array}{l}\text { 3. Ladder for accessing trailers } \\
\text { Employees were observed standing on a } \\
\text { standard a-frame ladder while applying } \\
\text { force and ratcheting the strap to hold } \\
\text { the drums in place. Their position with } \\
\text { one foot on the ladder, one foot on the }\end{array}$ & $\begin{array}{l}\text { a. Trailer Access Ladder } \\
\text { A ladder specifically designed for use with a tractor } \\
\text { trailer is recommended. Numerous vendor sources } \\
\text { are available. One possible option is shown below. }\end{array}$ \\
\hline
\end{tabular}




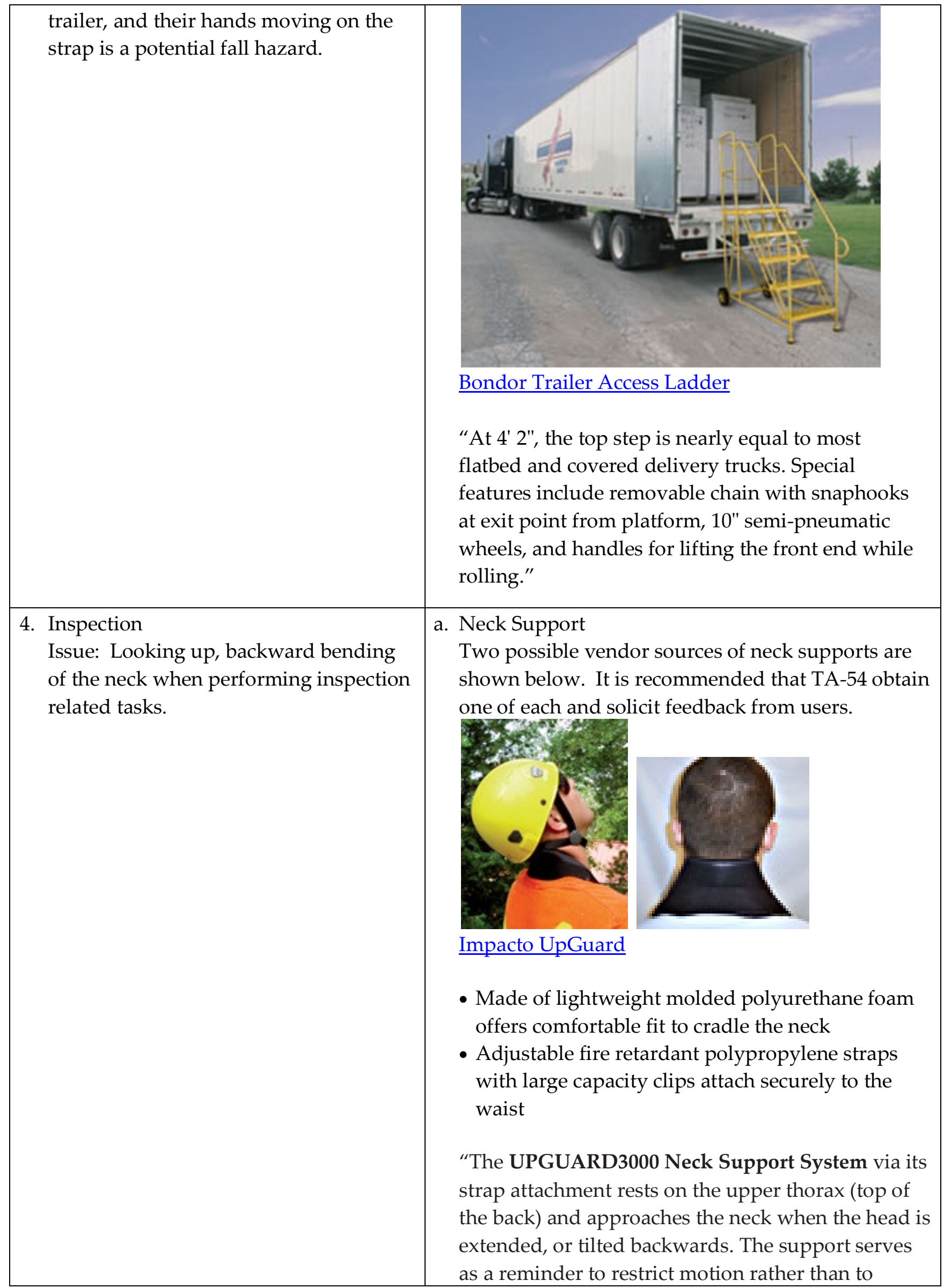




\begin{tabular}{|l|l|}
\hline $\begin{array}{l}\text { completely block motion. With the support resting } \\
\text { on the upper back, the extension range of motion } \\
\text { can be limited." }\end{array}$ & $\begin{array}{l}\text { Skan Technologies Neck Aid } \\
\text { "The NeckAid product is designed to reduce neck } \\
\text { pain while working overhead by supporting the } \\
\text { head when tilted back, yet, due to its patented } \\
\text { design, does not impede head movement when the } \\
\text { head is in an upright position. By supporting the } \\
\text { head, the muscles of the neck and shoulders can be } \\
\text { relaxed allowing the user to remain engaged in } \\
\text { many activities for prolonged periods of time." }\end{array}$ \\
\hline
\end{tabular}

Distribution:

Donald Thorpe, OS-PT, Project-Program Director

Joe P. Abeyta, OS-PT, Engineering Manager

Scott Miller, LTP-SSS, Environmental Manager

Garry Schramm, ESHQ-DR, ESH\&Q Manager

Alfred Vallo, LTP-SSS

Juan Garcia, LTP-SSS

Vicky Carrejo, IHS-CS File, Group Admin 


\section{Appendix A: Horizontal Push/Pull Recommendations}

"Pushing is generally preferable to pulling. Pushing allows the employee to use large muscle groups and apply more force to the load. Pulling carries a greater risk of strain and injury." (OSHA) "A worker is three times more susceptible to low back injury if he or she is performing a job which less than $75 \%$ of the working population can perform without overexertion." (Snook, Campanelli, and Hart 1978).

When evaluating pushing and pulling tasks, the force values refer to the applied force required to push or pull an object to initiate movement in either a horizontal or vertical direction, not the weight of the object being pushed or pulled. As with lifting, a variety of tools are available to ergonomists to calculate recommended maximum push/pull forces under specific work conditions. Recommended push/pull forces are dependent on the specific characteristics of the task including the height of the push/pull, the direction of the force, and the travel distance.

\section{Liberty Mutual Tables}

One source for this data is the Liberty Mutual Manual Material Handling Tables. These psychophysical data tables are commonly used to analyze frequent pushing, pulling, and carrying tasks.

An example analysis of a simulated pushing of drum task using Liberty Mutual Manual Material Handling Tables
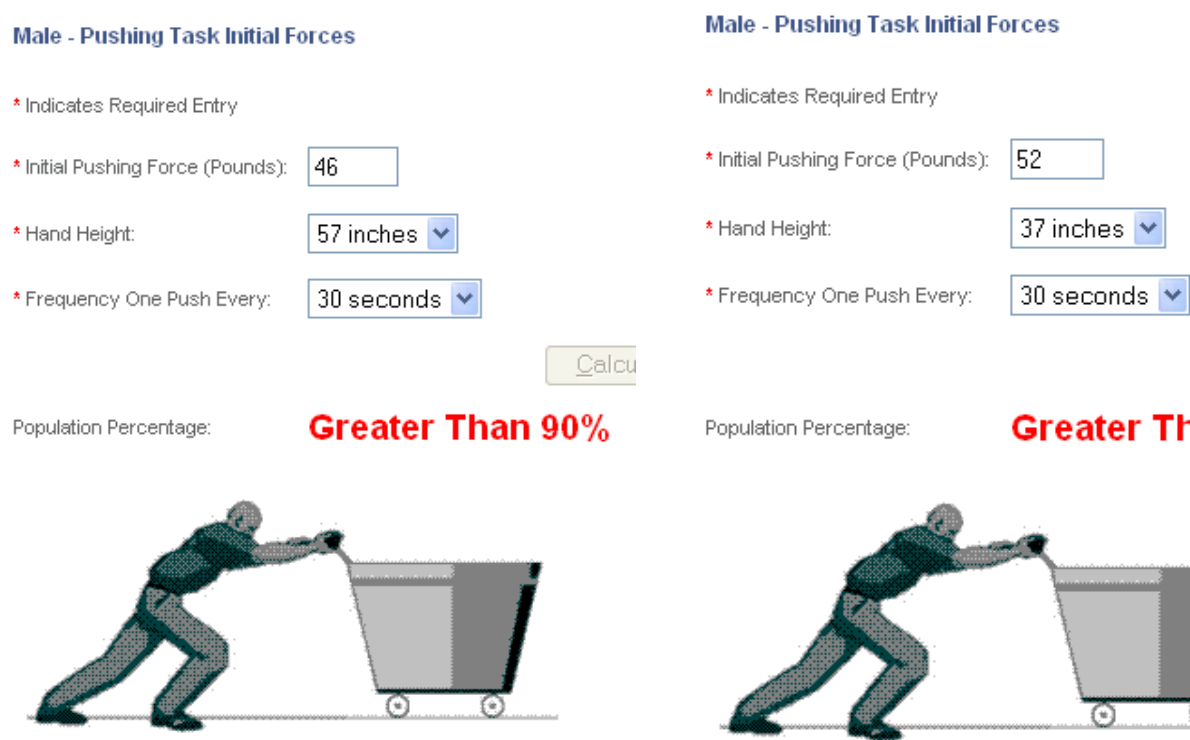

Population Percentage:

Greater Than $\mathbf{9 0} \%$

As shown in the graphics above, this analysis tool provides a recommended maximum 46 lbs initial push force at a push height of 57" and a maximum 52 lbs initial push force at a push height of 37" once every 30 seconds. 
Similar data from the Liberty Mutual tables for a two handed pull are shown in the table below.

\begin{tabular}{|l|l|l|l|}
\hline \multicolumn{4}{|l|}{ Maximum Initial Two Handed Pull Force } \\
\hline $\begin{array}{l}\text { Vertical Height of } \\
\text { Hands }\end{array}$ & $\begin{array}{l}\text { Frequency: } \\
\text { once every 8 } \\
\text { hours }\end{array}$ & $\begin{array}{l}\text { Frequency: } \\
\text { once every 30 } \\
\text { minutes }\end{array}$ & $\begin{array}{l}\text { Frequency: } \\
\text { once every 5 minutes }\end{array}$ \\
\hline $\mathbf{2 5 \prime}$ & $80 \mathrm{lbs}$ & $65 \mathrm{lbs}$ & $65 \mathrm{lbs}$ \\
\hline $\mathbf{3 7 \prime}$ & $72 \mathrm{lbs}$ & $59 \mathrm{lbs}$ & $58 \mathrm{lbs}$ \\
\hline $\mathbf{5 7 \prime}$ & $50 \mathrm{lbs}$ & $41 \mathrm{lbs}$ & $41 \mathrm{lbs}$ \\
\hline
\end{tabular}

The data in the table are for $90 \%$ of the male population working at three different hand heights performing a two handed pull.

\section{Mital Psychophysical Data}

Pushing with both hands, standing, no anchor for foot support (operator selecting foot distance and height of force application).

\begin{tabular}{|l|l|l|}
\hline \multicolumn{2}{|l|}{ Recommended Isometric Push Forces* } \\
\hline Condition & Criteria & Recommended Force Limit \\
\hline $\begin{array}{l}\text { Very Slippery } \\
\text { (coefficient of friction 0.3) }\end{array}$ & $75 \%$ of population & $37 \mathrm{lbs}$ \\
\hline $\begin{array}{l}\text { Moderately Slippery } \\
\text { (coefficient of friction 0.6) }\end{array}$ & $75 \%$ of population & $57 \mathrm{lbs}$ \\
\hline
\end{tabular}

*Mital, A., A.S. Nicholson, and M.M. Ayoub. A Guide to Manual Materials Handling, Second

Edition. Taylor \& Francis, 1997.

\section{Canadian Center for Occupational Health and Safety}

\section{Two Handed Push/Pull}

The Canadian Centre for Occupational Health and Safety provides recommended maximum force limits for two handed pushing/pulling.

\begin{tabular}{|l|c|l|}
\hline \multicolumn{3}{|c|}{ Recommended Upper Force Limits for Horizontal Pushing: Two Hands** } \\
\hline Condition & $\begin{array}{l}\text { Forces that should } \\
\text { not be exceeded }\end{array}$ & Example task \\
\hline Standing, whole body exertion & $45 \mathrm{lbf}$ & $\begin{array}{l}\text { Pushing cart or other equipment on } \\
\text { wheels, Sliding rolls on shafts. }\end{array}$ \\
\hline $\begin{array}{l}\text { Standing, primary arm and } \\
\text { shoulder muscles, arms fully } \\
\text { extended }\end{array}$ & $24 \mathrm{lbf}$ & $\begin{array}{l}\text { Pushing at or above shoulder height; } \\
\text { pushing while leaning over an } \\
\text { obstacle }\end{array}$ \\
\hline
\end{tabular}

* *adopted from: Ergonomic design for people at work. Vol. 2, by Eastman Kodak Company, Van Nostrand Reinhold, 1986 


\section{Appendix B: Additional Equipment Resources}

Vendor sources for drum handling equipment include:

- Advanced Handling Services

- $\underline{\text { LK Goodwin }}$

- Lift-o-Matic

- Drum Runner

- $\underline{\text { Basco }}$

- SEI Equipment

- Vestil Manufacturing

- Morse Mfg

- Wesco

- NewPig

- Easy Lift Equipment

Special or modified equipment may be required to meet unique or specific needs. In some situations, dedicated equipment may be appropriate. In other situations attachments for use with existing cranes, hoists, or lift trucks may be more appropriate. The following list may be considered as a starting point for ideas of the types of standard equipment readily available. Additional sources can be found at a variety of online vendor locations including the Material Handling Industry of America website.

\begin{tabular}{|l|l|}
\hline Equipment for Placing Drums on and off Pallets \\
\hline NARROW AISLE 27" WIDE "SL" MODEL
\end{tabular}




\begin{tabular}{|c|c|}
\hline & $\begin{array}{l}\text { - Non-sparking jaws with rubber belt and } \\
\text { anti-static grounding strap } \\
\text { - } 8 \text { " wheels for rough surfaces } \\
\text { - Scales with or without intrinsically safe } \\
\text { indicators } \\
\text { - Air tank pneumatic lift for hazardous areas } \\
\text { - Jib for handling drums into containment } \\
\text { vessels }\end{array}$ \\
\hline $\begin{array}{l}\star \star \star \star \star \star \\
\text { MADE IN USA } \\
\end{array}$ & $\begin{array}{l}\text { Wesco Powered Drum Handler } \\
\text { - Battery powered - takes the strain out of } \\
\text { moving heavy drums. } \\
\text { - Variable speed forward and reverse. } \\
\text { - Circuit breaker protection. } \\
\text { - Magnetic clutch allows the drive wheels to be } \\
\text { free wheeling. } \\
\text { - Wheel brake bands activated by hand lever. } \\
\text { - Nose prongs reversible for use with } 30 \text { and } 55 \\
\text { gallon drums. } \\
\text { - Two chime hook choices. } \\
\text { 1. SCH: Short Chime Hook used on standard } \\
\text { closed head 55 gal. steel, fiber and poly drums. } \\
\text { Also on standard drums with locking rings. } \\
2 . \text { LCH: Long Chime Hook used only on steel } \\
85 \text { gal. drum with locking ring. LCH models } \\
\text { not listed. } \\
\text { - Handles } 30-50-85 \text { gallon poly and steel drums. } \\
\text { - Capacity 1000 lbs. } \\
\text { - Front wheels } 10 " \text { moldon rubber } \\
\text { - Rear wheels 6" polyurethane } \\
\text { - Dimensions } 60 " \text { tall, } 26 " \text { wide }\end{array}$ \\
\hline & $\begin{array}{l}\text { Morse Manufacturing } 750 \text { Pallet Server } \\
\text { - MOR Speed head grabs rimmed steel, fibre or } \\
\text { plastic drums } \\
\text { - } 4^{\prime \prime} \text { swivel caster for steering } \\
\text { - } \text { 8" polyolefin load wheels with roller bearings for }^{\prime \prime} \text { easy rolling } \\
\text { - Tilter directs lifter for right or left drum } \\
\text { - Up/down control valve on hand control } \\
\text { - Pneumatic cylinder for quick raising and } \\
\text { lowering of drums }\end{array}$ \\
\hline
\end{tabular}




\begin{tabular}{|c|c|}
\hline DM-1100 & $\begin{array}{l}\text { Wesco DM1100 with Gator Grip } \\
\text { Revolutionary patent-pending design available } \\
\text { only from Wesco. Wesco's exclusive auto grip lock } \\
\text { automatically locks the grip jaws closed. Even } \\
\text { over rough terrain, the Wesco Gator Grip } \\
\text { maintains a positive lock } \\
\text { - lifting, transporting, and placing drums on } \\
\text { spill pallets or standard pallets. } \\
\text { - No need for the operator to touch the drum to } \\
\text { raise, transport or lower } \\
\text { - 1,100 lb capacity hydraulic jack for easy lifting } \\
\text { of steel, poly and fiber drums. } \\
\text { - Spring loaded clamp holds any } 3 / 16 \text { " or higher } \\
\text { rimmed drum } \\
\text { - Ergonomic design allows drums to raise } 20 " \\
\text { above the floor with } 1 \text { " rise/stroke } \\
\text { - Swivel casters for easy movement and steering } \\
\text { - Floor lock } \\
\text { - Handles most standard } 30,55, \text { and } 85 \text { gallon } \\
\text { drums } \\
\text { - Exclusive atuo grip lock will not drop a drum } \\
\text { - Legs Extended: length: } 37 \text { ", width: } 41 \text { " } \\
\text { - Capacity: } 650 \text { lbs, Length: } 34.5 \text { ", Width: } 36 \text { " } \\
\text { - Casters: } 5 \text { " x } 2 \text { Phenolic caster }\end{array}$ \\
\hline & $\begin{array}{l}\text { New Pig Aluminum } \\
\text { - Light-weight, corrosion-resistant aluminum is } \\
\text { non-sparking; safer than steel for use around } \\
\text { flammables } \\
\text { - Spring-loaded chime hook automatically drops } \\
\text { to engage drum and prevent sliding or falling } \\
\text { drums } \\
\text { - Stable, 4-wheel design lets you easily move } \\
\text { drums on and off pallets without strains or } \\
\text { tipovers } \\
\text { - Large pneumatic tires offer a smooth, } \\
\text { cushioned ride even on rough surfaces; brake } \\
\text { helps you control heavy loads } \\
\text { - Load capacity } 700 \text { lbs. }\end{array}$ \\
\hline
\end{tabular}




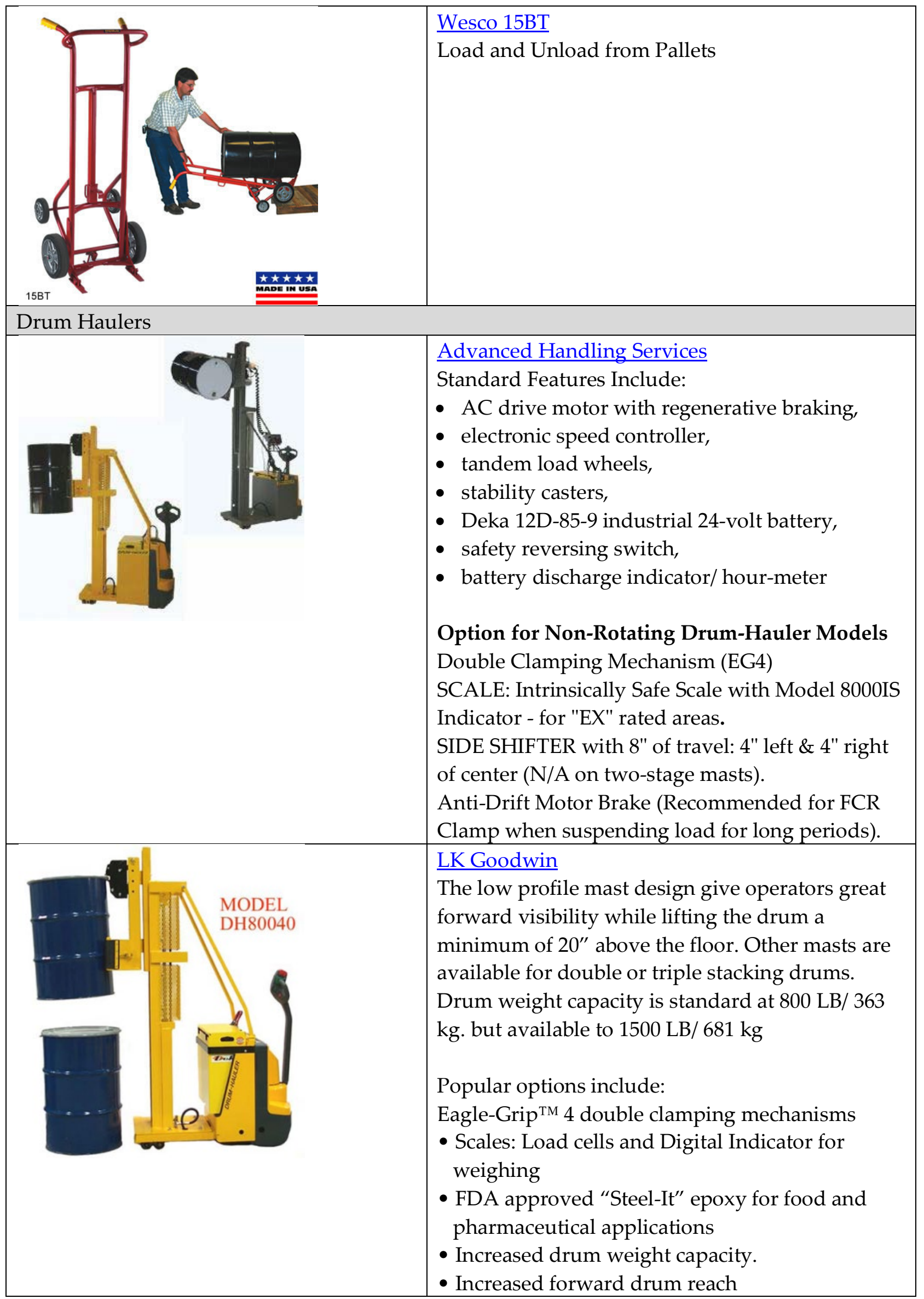




\begin{tabular}{|c|c|}
\hline $\begin{array}{l}\text { MODEL } \\
\text { DH800 }\end{array}$ & $\begin{array}{l}\text { LK Goodwin } \\
\text { Equipped with Eagle-Grip }{ }^{\mathrm{TM}} \text { single or } \\
\text { double automatic clamping mechanism, } \\
\text { Drum-Haulers }{ }^{\mathrm{TM}} \text { provide the safest handling } \\
\text { method for all chimed plastic, fibre and steel } \\
\text { drums. The all powered lift and travel } \\
\text { features allow any operator to: } \\
\text { - Handle drums in tightly confined areas } \\
\text { and aisles } \\
\text { - Transport up and down ramps or inclined } \\
\text { floors } \\
\text { - Remove or place drums on the side of a } \\
\text { pallet, floor scale, conveyor or secondary } \\
\text { containment pallet } \\
\text { - Remove or place drums inside flammable } \\
\text { storage cabinets or drum warming ovens } \\
\text { - Load or unload trucks, trailers and oversea } \\
\text { shipping containers either single or double } \\
\text { stacked }\end{array}$ \\
\hline \multicolumn{2}{|l|}{ Forklift Attachments } \\
\hline 1500 ib. Capacity & $\begin{array}{l}\text { Global Industrial } \\
\text { Single Fork Mounted Drum Gripper } \\
\text { Allows the operator to lift, transport, and deposit } \\
\text { steel drums without leaving the seat of the fork } \\
\text { truck. Mounts easily on the forks, just hand } \\
\text { tighten lock screws, no tools required. The } \\
\text { knuckle gripping system is lowered around the } \\
\text { drum, gripped tightly, and then lifted. The weight } \\
\text { of the drum holds grab jaws in place to minimize } \\
\text { slippage. Drum is automatically released by } \\
\text { lowering the forks. Welded steel construction. } \\
\text { Features hinged folding arm design to save } \\
\text { storage space. Powder coat yellow finish. } \\
\text { Adjustable models are painted red. }\end{array}$ \\
\hline & $\begin{array}{l}\text { Basco Super Duty Adjustable Fork Mounted } \\
\text { Drum Grabbers } \\
\text { - Lift, transport and lower drums without } \\
\text { leaving the driver's seat } \\
\text { - Drum Models for 15, 30, } 55 \text { and } 85 \text { gallon } \\
\text { ribbed steel drums } \\
\text { - Single and double drum models, up to } 1500 \\
\text { lbs. capacity per drum }\end{array}$ \\
\hline
\end{tabular}




\begin{tabular}{|l|l|}
\hline & $\begin{array}{l}\text { These dumpers are the Cadillacs of the industry, } \\
\text { with the highest load capacity of any grabber. } \\
\text { Adjustable to accept 15, 30, 55, or 85 gallon drums, } \\
\text { depending on the model. Just drive up to the } \\
\text { drum and lower the forks as you continue } \\
\text { towards the drum. The unique cam operation } \\
\text { spreads the curved grabber arms and engages } \\
\text { them with the drum. Lifting the forks locks the } \\
\text { arms tightly around the drum. }\end{array}$ \\
$\begin{array}{l}\text { All VF Series Grabbers work with any fork width } \\
\text { or thickness but require a 22-1/2" maximum } \\
\text { outside fork spread. Available with spark resistant } \\
\text { brass liners on grabber arms. }\end{array}$ \\
\hline
\end{tabular}




\section{Appendix C: Example of Technique Training for Drum Handling}

Reprinted from Brassmein.com: Information Resources for Construction Industry Employment and Operations

\section{Safe Handling 55 Gallon Drums \\ by Susan McElrath}

At least four serious injuries can occur if a 55 Gallon Drum is not handled safely:

- fractures

- lacerations

- hernias

- back strain

All these injuries are painful and require a long time to heal. By taking a few precautions before you attempt to move a drum, you can help prevent these serious and painful injuries.

Before you move a drum, put on a pair of thick gloves. The gloves will help protect your hands. Also follow this preliminary checklist:

- Check to see how much room there is to move the drum.

- Plan your route in advance. Don't wait until the drum is in motion.

- Check the route for anything that might cause you or your equipment to trip or slip.

- Check the drum to make sure it isn't warped. This could cause the drum to slip.

- Check the drum for burrs which could cause a laceration.

- Check the drum for liquids which could cause you to lose your grip.

- Check the bung to make sure it is tight enough to prevent leaks.

- If you are moving the drum using a pallet, make sure the pallet is in good condition.

There are four ways to "break," or initially move a 55 Gallon drum from its standing position. These are pulling, pushing, or combinations of pulling and pushing, the drag/pull method and the push/pull method. Pulling is necessary when 55 Gallon drums are grouped closely together. Pushing is used when there is ample room to work. The drag/pull method is used when there are tight spots in the area you are "breaking" the 55 Gallon drum. The push/pull method is used when drums are located beside a wall.

To pull the 55 Gallon drum, grip the near chime with one hand and the far chime with the other. Brace your foot at an angle across the bottom chime. Your hands and feet should form a straight line. Check the position of your fingers for possible pinch points. Now you are ready to pull back on the drum.

To push the 55 Gallon drum, place your hands near the chime at shoulder width. Move your shoulders low and close to the drum. Slowly push forward with your legs until you feel the drum reach its balance point.

When using the drag/pull method, place your hands at the near position at shoulder width. Brace the drum with your foot to prevent it from sliding, and shift your weight to the rear foot. Pull and drag it a few inches to the left then to the right. 
To use the push/pull method, use one hand to pull the far chime. Use the other hand to push against the wall.

If a 55 Gallon drum starts to fall, get away from it as quickly as possible. If the contents spill, follow your worksite's procedures for reporting a spill.

If two people are moving a 55 Gallon drum, both people can push the drum, pull the drum, or one can push while the other pulls. When rolling the drum, it is safer for one person to roll it.

To roll a 55 Gallon drum, in this case to the left, follow these steps:

- Place your left hand high on the chime and your right hand low.

- Use both hands to roll the drum.

- As your right hand reaches the top, quickly switch the left hand to the top position.

- Lift your hands and place them into position. Do not slide your hands because you may cut or burn them.

- Keep your feet separated and do not slide them. Use the side step.

- Turn your body slightly away from the drum, but not too far away.

- Stay close and ahead of the drum.

When you reach your destination, place the 55 Gallon drum in its position using the reverse of the push, pull, drag/pull, or push/pull method. 


\section{Appendix D: Excerpt from DOE Explosive Safety Manual}

\subsection{TRANSPORTATION}

\subsection{Equipment and Operations}

\subsubsection{Materials Handling Equipment}

a. Gasoline-powered materials-handling equipment (e.g., forklifts, etc.) may be used only in areas where all explosives are properly packaged and only if equipped in the following manner.

(1) Backfire deflectors shall be the oil-bath or screen type (certain types of air cleaners will serve the purpose) and shall be attached securely on the throat of the carburetor.

(2) A tight-fitting, properly vented cap, shall be in place on the gasoline fill pipe at all times (except during refueling).

(3) A flame arrestor shall be installed in the fill pipe.

(4) If necessary, a deflector plate shall be installed to prevent any gasoline tank overflow from reaching the motor or the exhaust pipe.

(5) On gravity feed systems or on pump systems where siphoning might occur, a shutoff valve shall be installed at the fuel tank or in the feed line to permit shutting off the flow of gasoline in an emergency or a break in the fuel line or carburetor.

(6) Provisions shall be made to prevent fuel lines from rupturing due to vibration.

b. Diesel-powered equipment may be used if all the precautions for gasolinepowered equipment (as specified above) are followed.

c. Battery-powered equipment for handling explosive material shall comply with the criteria listed below.

(1) Battery-powered equipment and its use in hazardous locations shall comply with OSHA standards. All equipment shall be appropriately labeled for ready identification.

(2) Types E, EE, ES, and EX rated, battery-powered equipment are satisfactory for handling all classes of properly packaged ammunition and explosives. Types EE and ES battery-powered equipment may be used to handle packaged explosives or components in corridors or ramps connecting hazardous operations, provided the ramps and corridors are not Class I or II, Division 1, hazardous locations (NEC). Type EE equipment is authorized for use in Class II, Division 2, Group G hazardous locations, and Type ES equipment may be authorized with facility management's approval (see NFPA 505, Powered Industrial Trucks).

(3) Only Type EX equipment is approved for use in specifically named Class I, Division 1, Group D or Class II, Division 1, Group G hazardous locations. At this time, EX equipment does not carry a dual rating and shall only be used in hazardous areas for which it is specifically rated. 